\title{
Announcement
}

\section{ECONOMIC HISTORY ASSOCIATION ANNUAL MEETING}

The forty-first.annual meeting of the Economic History Association will take place at the Chase Park Plaza Hotel, St. Louis, MO, September 17-19, 1981. The preliminary program is as follows:

\section{New Studies on British Imperialism}

Lance E. Davis, California Institute of Technology, and Robert A. Huttenbach, University of California, Santa Barbara, "The Political Economy of British Imperialism: Measures of Benefits and Support"

B. R. Tomlinson, University of Birmingham, "The Political Economy of the Raj: The Decline of Colonialism"

\section{Marxist Approaches to Economic History}

Stephen A. Resnick, University of Massachusetts, Amherst, and Richard D. Wolff, University of Massachusetts, Amherst, "Recent Reformulations in Marxian Theory and Their Implications for Research in Economic History"

Susan Feiner, College of William and Mary, "Southern Merchants and Planters: Class Relations in the Ante-Bellum Period"

Rolf Jensen, Connecticut College, "The Transition from Classless to Class Society: The Wolof in Precolonial Senegal"

Rona Weiss, Iona College, "Primitive Accumulation in the United States: The Interaction between Capitalist and Non-capitalist Class Relations in Seventeenth Century Massachusetts"

\section{Canadian Agriculture}

R. Marvin McInnis, Queens University, “Agricultural Exports and Productivity in Late Nineteenth Century Canada"

Trevor J. O. Dick, University of Lethbridge, "Mechanization and North American Prairie Farm Costs, 1900-1930"

Robert E. Ankli, Guelph University, "From Wheat to Cheese: Ontario Agriculture in Transition"

\section{Victorian Britain}

Barry J. Eichengreen, Harvard University, "The Proximate Determinants of Domestic Investment in Victorian Britain"

William H. Phillips, University of South Carolina, "Induced Innovation and Economic Performance in Late Victorian British Industry"

W. P. Kennedy, University of Essex, "Economic Growth and Structural Change in the U.K., 1870-1914"

\section{Money, Banks, and Regulation}

Richard Sylla, North Carolina State University, "Monetary Innovation in America"

Eugene White, Rutgers University, "The Competitive Regulation of U.S. Banking, 19001929"

Robert Zevin, United States Trust Company, "The Economics of Normalcy" 
Women's Employment History

Susan B. Carter and Mark Prus, University of Utah, "Women's High School Attendance and Employment Opportunities in Turn of the Century America"

Susan A. Matthies, Stanford University, "Women at Work: A Comparative Analysis of Female Labor in the Cotton Textile Industry, 1910"

Peter Philips, University of Utah and Georgia State University, "Gender-Based Wage Differentials in Pennsylvania and New Jersey Manufacturing, 1895 to 1900"

Economic Development of Early Modern Europe

Dennis O. Flynn, College of the Pacific, "Fiscal Crisis and the Decline of Spain"

Michael Weiser, University of South Carolina, "The Agrarian Depression in Seventeenth Century Spain"

Phillip Hoffman, California Institute of Technology, "Urban Investment in the Countryside of Southern France during the Seventeenth Century"

\section{Presidential Address}

Jonathan R. T. Hughes, Northwestern University, "The Great Strike at Nushagak: Institutional Gridlock"

\section{Workshops*}

Hyperinflation in the Twentieth Century; Convener: Steven B. Webb, University of Michigan

Energy Pricing and Technology; Convener: William J. Hausman, University of North Carolina, Greensboro

Urban and Regional Economies; Convener: Diane Lindstrom, University of Wisconsin

Quantitative Third World Economic History; Convener: David Feeny, McMaster University

* There are still a number of places open for individuals wishing to make presentations in the workshops. Contact the convener directly if interested. The names of those giving such presentations will appear in the official program of the annual meeting. 